\title{
THE GREAT WHITE SHARK Carcharodon carcharias (LINNÉ, 1758) IN THE PLIOCENE OF PORTUGAL AND ITS EARLY DISTRIBUTION IN EASTERN ATLANTIC
}

\author{
Miguel Telles ANTUNES $S^{1,2,3}$ and Ausenda Cáceres \\ BALBINO ${ }^{3,4}$
}

${ }^{1}$ Academia das Ciências de Lisboa, Rua da Academia das Ciências, 19, 1249-
122 Lisboa, Portugal.
${ }^{2}$ European Academy of Sciences, Arts and Humanities, Paris, France.
migueltellesantunes@gmail.com
${ }^{3}$ Centro de Investigação em Ciências e Engenharia Geológica, Faculdade de
Ciências e Tecnologia da UNL, 2826-516 Caparica, Portugal.
${ }^{4}$ Departamento de Geociências, Universidade de Évora, 7000. acaceres@uevora.pt

Antunes, M. T. \& Balbino, A. C. 2010. The great white shark Carcharodon carcharias (Linné, 1758) in the Pliocene of Portugal and its early distribution in eastern Atlantic. [El gran tiburón blanco Carcharodon carcharias (Linné, 1758) en el Plioceno de Portugal y su presencia más antigua en el Atlántico oriental.] Revista Española de Paleontología, 25 (1), 1-6. ISSN 0213-6937.

\begin{abstract}
Fossil great white shark Carcharodon carcharias has been recognized for the first time in Portugal near Marinha Grande in Pliocene sediments. This occurrence further broadens its already huge distribution. It is indeed the first Pliocene shark so far identified in Portugal.

The great white shark is represented but by a single upper right lateral tooth lost after use from a ca. $4 \mathrm{~m}$ TL, adult individual.

The presence is very much in agreement with all known data about Iberian Peninsula, where it really has never been found in Miocene units but becomes common in lower Pliocene levels in Spain.

Although the evidence is typical, it is too scarce to allow much speculation on the species numerical importance. If however we take into account that no other shark teeth are known in the concerned sediments it can provisorily be accepted that its occurrence would be rather common.

This new record for the Pliocene in Portugal underlines the closeness of the first known occurrences for the eastern Atlantic, both in its northern (as this is the case) and southern parts as shown by the referred Pliocene fauna of Farol das Lagostas, Angola.
\end{abstract}

Key words: Sharks, Carcharodon carcharias, distribution, Pliocene, Portugal, eastern Atlantic.

\section{RESUMEN}

Se ha reconocido el gran tiburón blanco Carcharodon carcharias por primera vez en Portugal, en sedimentos pliocenos cerca de Marinha Grande. Este hallazgo aumenta más su ya amplia distribución. Además, es el primer tiburón identificado en el Plioceno de Portugal.

El gran tiburón blanco está representado por un único diente lateral derecho superior de un individuo adulto, con unos $4 \mathrm{~m}$ de longitud total, perdido después de su uso.

Su presencia es coherente con los datos de la Península Ibérica, donde nunca se ha encontrado en unidades miocenas, pero es común en niveles del Plioceno inferior español.

Aunque la evidencia es clara, es demasiado escasa para permitir especulaciones sobre la importancia numérica de la especie. Sin embargo, si tenemos en cuenta que no hay otros dientes de tiburón conocidos en los sedimentos involucrados, provisionalmente se puede aceptar que su presencia podría ser bastante común.

Este nuevo registro para el Plioceno de Portugal subraya la cercanía de este primer hallazgo para todo el Atlántico oriental, tanto en su parte septentrional (como es este caso) como para el Atlántico Sur como señala la fauna pliocena referida en el Farol das Lagostas (Angola).

Palabras clave: Tiburones, Carcharodon carcharias, distribución, Plioceno, Portugal, Atlántico oriental. 


\section{INTRODUCTION}

Few animals have attracted as much attention as the very top large-prey predator of the pyramid series as the great white shark, Carcharodon carcharias (Linné, 1758). This happened since a long time ago, as it has even been clearly depicted from at least the XVIth century, i.e. by Rondelet. Their occurrences have been registered in the Mediterranean and elsewhere, because it really has a world-wide geographic distribution in somewhat warm to temperate waters of all the main oceans. As far as we know, it avoids cold temperate and cold seas, and otherwise tends to be replaced in warm waters by its competitor in size and force, the tiger shark Galeocerdo cuvier (Peron \& Lesueur in Lesueur, 1822).

Its power, large size, and elegance, as well as its record about attacks on humans attract a growing public attention on the white shark. Its biology, the wide variety of environmental conditions where it can occur its displacements and migrations, have often been dealt with, along with overfishing, extinction dangers and protective measures.

Its origin has also been discussed. As far as its first occurrence is concerned, it appeared quite late in the History of the Earth, a few million years ago. In Europe at least, as in Belgium, the earliest certain occurrences concern Pliocene sediments (Hubbell, 1996: 422-425, 465), "C'est une espèce rare, en Belgique, dans les formations néogènes antérieures au Scaldisien. Elle devient plus commune dans ce dernier étage, où elle semble remplacer $\mathrm{C}$. megalodon" (Leriche, 1926: 424). Both species occur in Belgium (Hubbell, 1996: 465) in the Pliocene stages Anversian, Diestian and Scaldisian, yet not before.

The same seems to apply to the western Atlantic occurrences in North America. It occurs in Pliocene beds from Farol das Lagostas near Luanda, Angola, definitely in association with the maybe last representatives of the huge Carcharocles megalodon (Agassiz, 1843) see Antunes (1978). The latter is a well known Miocene form that seems to have been severely hit by main oceanographic changes by the end of the Miocene and as a result became scarcer and increasingly rare until its ultimate extinction, maybe in Pleistocene times. A Pleistocene age was accepted for great depth, bottoms' phosphatised fossil teeth, but they may be older in hard ground conditions where heterochrony may be very marked. The white shark seems to have gained from the extinction of this formidable counterpart. It acquired an increased importance and a very broad distribution.

However, C. carcharias is stated to occur earlier. Indeed there where some reports in which teeth correctly ascribed to Carcharodon carcharias have been regarded as early as lower Miocene in age, but those rare specimens' origin are erroneous.

In a recent revision (Andres, in press) "The Great White Shark (Carcharodon carcharias LINNAEUS, 1758) as a species can be traced back until the early Pliocene (5 mya). Its fossil teeth ... can be found worldwide in almost all marine sediments of the correct age, e.g. in the Pliocene of Cadzand/Netherlands, Antwerp/Belgium, Almeria/Spain, Piacenza Province/N Italy, Aurora/NC/USA, Florida/USA, Sacaco/Peru, Caldera/Chile and Sapolwana/Kwazulu-Natal/South Africa as well as in the Pleistocene of Charlotte County/Florida/USA and Naganuma Yokohama/Japan. Teeth found in Miocene (15-13.5 mya) sediments are typically slightly rolled, have a more or less eroded root (e.g. those from Bakersfield/Kern County/CA/USA and Aurora/ $\mathrm{NC} / \mathrm{USA}$ ) and have been reworked from Pliocene (5.3-1.6 mya) into Miocene (23.8-5.3 mya) sediments (links: www. elasmo.com/paleo/sth/sa-c_car.html).

As far as Portugal is concerned, rich Miocene selachian faunas have been described (Antunes, 1970; Balbino, 1995). Carcharocles megalodon (Agassiz, 1843) is quite often present in middle and upper Miocene beds in Lisbon and Setúbal Peninsula. Later on, the same species has been found in uppermost Miocene as in the Alvalade basin in southern Portugal (Esbarrondadoiro Formation) and in Algarve (Cacela Formation): C. megalodon is known in both these formations, but no Carcharodon carcharias remnants have ever been found there.

Things were changing with the Messinian crisis. Mediterranean closed and was reduced to an inland sea whose oversaline conditions led to huge evaporite deposits and to the extinction of much of the fish fauna. After communication with the Atlantic was restablished in early Pliocene, C. megalodon may have entered again into the Mediterranean, but now along with Carcharodon carcharias.

Fossil localities in Europe (i.e. in Italy and Spain) yielded $C$. carcharias, but megalodon seemed already extinct (Adnet et al., in press). Hence an origin of C. carcharias in Pliocene times seemed possible as far as European data are concerned. All the concerned data are very useful in discussing the origin and occurrence of the great white shark.

As stated earlier, no fossil great white shark was known in Portugal, where no Pliocene selachian faunas had so far been discovered. However, one of us (M.T.A.) recalled a reference he once, long ago had read to a "Carcharodon megalodon" tooth collected near Marinha Grande. In this region there are extensive outcrops of Pliocene marine sediments related to an important transgression event that had effects in the Mondego basin, west-central Portugal. Miocene marine beds are not represented in the same region.

The specimen was found at Matos, a hamlet about 1.5 $\mathrm{km}$ to the SE from the centre of Marinha Grande. According to Morais (1941: 3) fossils had been collected by Mr. Malaquias das Neves in sediments extracted during the opening of a well at his propriety. Under a sandy, cultivated soil bed about one meter in thickness there are more pure, sometimes consolidated sands with very well preserved fossils. These sands yielded the shark tooth under study. 
The owner of the propriety gave fossils he had found to the late José Custódio de Morais, then a Professor at the Coimbra University. Most of which are kept at the Mineralogical and Geological Museum from the same University, including the tooth under study here. It was referred to as Carcharodon megalodon by Morais, who specified that the fossil's identification had been made by Leslie Reginald Cox, from the Natural History Museum in London (Morais, 1941: 4-5); for an earlier account on the fossilbearing sediments, see Morais (1936). The specimen had never been depicted nor described, even in paleontological papers that dealt with the associated malacologic fauna (Cox, 1936; Compagno et al., 2005).

The supposed presence of Carcharocles megalodon in the concerned Pliocene, Mondego basin unit has been forgotten for long. As far as we know, it was referred to but by Zbyszewski (1965: 8-9, list of fossils).

In the general context, such an occurrence would be worthwhile to verify, either if the specimen still existed or, if yes, if systematic determination as Carcharodon megalodon was correct because at such relatively modern age confusion with Carcharodon carcharias could well be possible. Hence we asked our Colleague, Pedro Callapez, which is in charge of the Coimbra Museum collections, if the Matos' tooth could be located and studied. Callapez promptly searched with success, allowing us to proceed. The results are as follows.

\section{DESCRIPTION AND COMPARISONS}

In the following text, we adopt the classification according to Cappetta (2006).

Class CHONDRICHTHYES Huxley, 1880 Subclass ELASMOBRANCHII Bonaparte, 1838

Cohort EUSELACHII Hay, 1902

Order LAMNIFORMES Berg, 1958

Family Lamnidae Müller \& Henle, 1838

Genus Carcharodon Müller \& Henle, 1838

\section{Carcharodon carcharias (Linné, 1758)}

Fig. 1

Modern common names: Tubarão, tubarão-comedor-de-homens (Port.), Great white shark (Engl.), etc.

References concerning the specimen under study: Carcharodon megalodon; Cox in Morais (1941: 5).

Carcharodon megalodon Charlesworth; Zbyszewski (1965: 9).

Material and collection: One tooth. Collector: Mr. Malaquias das Neves. Museu Mineralógico e Geológico, a section of the $\mathrm{Mu}-$ seu da Ciência, Universidade de Coimbra, Portugal. File Number 496 on a small paper label glued on the specimen.
Site: A well at Matos, near Marinha Grande, western Central Portugal. Coordinates: Matos, Lat. 39 41' 2.920" N, Long. $8^{\circ}$ 59' 41.021" W. Another well from where fossil collecting was carried on: Guarda-Nova, Lat. $39^{\circ} 45^{\prime} 5.958^{\prime \prime} \mathrm{N}$, Long. $8^{\circ} 56^{\prime}$ 29.968" W. Carta Topográfica de Portugal 1:25,000, 1982, Marinha Grande sheet.

Stratigraphy: Coarse marine, often fossil-rich sands and conglomerates deposited during a Pliocene transgression event that attained the Mondego basin area. Molluscs are plentiful at some localities.

Age: The fossil-bearing sediments have long been regarded as Pliocene, Piacenzian (or "Astian") in age, as it was clearly stated by Dollfus \& Cotter (1908) see Cox (1941: XIV). More recently, the same sediments have been not much differently dated from uppermost Zanclean to lower Piazencian on mollusc and calcareous nannoplancton evidence - see Silva \& Landau (2007: 20). No up-to-dated study on planctic foraminifera seems to be available, nor is there any kind of radiometric dating. All in all, the above indicated age little differs from the more ancient one. An age of about 3.5 Ma seems to fit quite well enough.

Description: The specimen is complete and well preserved. As a whole, it is rather flat and very moderate in thickness, even in its lingual part, much less thick as usual in megalodon. There is no distinct, slightly depressed dental band in the basal part of the crown on the lingual side, as it typically occurs in megalodon (Applegate \& Espinosa-Arrubarrena, 1996: 21, fig.1).

The shape of the crown is a somewhat asymmetrical, triangular one with a slightly eccentric apex. There are ca. 8 degrees of slant (Hubbell, 1996: 10, fig.1). Both mesial and distal cutting edges are complete, except for a small damage with loss of enamel matter in the middle part of the mesial one. Damage also is shown by cutting denticles in a few recent teeth, also on more or less middle part of the mesial cutting border and not on the distal border too; denticles are entirely perfect in a replacement tooth whose root was not yet completely formed.

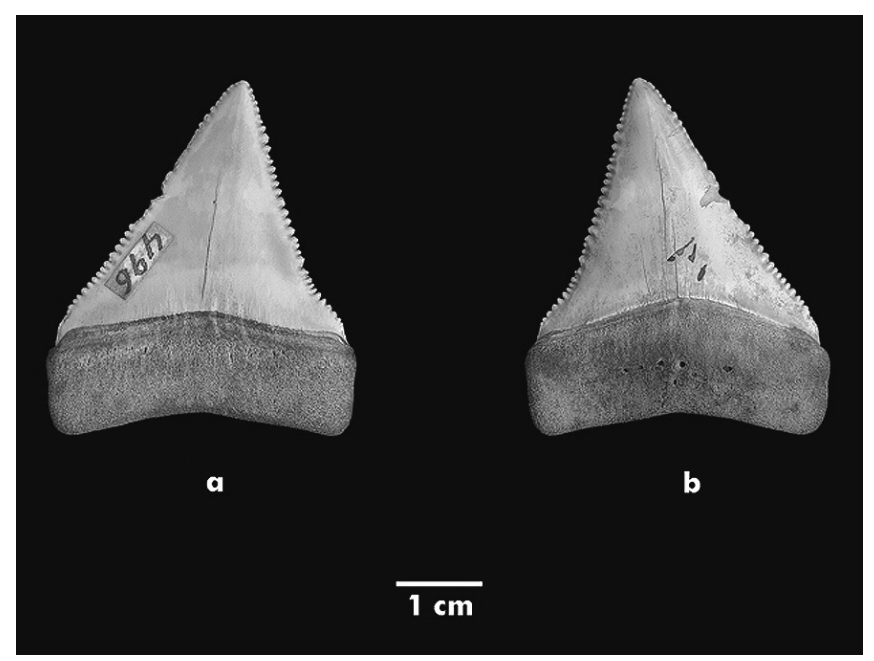

Figure 1. Pliocene, upper right lateral tooth of Carcharodon carcharias Linné, 1758 from Marinha Grande, Portugal (MCUCP, 496); labial (a) and lingual (b) views. 
Dimensions (mm):

- crown height (measured on the labial side), 31.3;

- crown width (idem), 33.2.

Extrapolations on the size (total length) of white sharks may be done through a linear regression that relates it to the height of the upper second anterior tooth. If we admit that there is some proportionality in dental linear dimensions, the $3 \mathrm{~d}$ file crown height would amount to ca. 0.8 from its larger counterpart [0.83 on the fig. 89 from Leriche (1926); 0.75 after fig. 1 from Applegate \& Espinosa-Arrubarrena (1996), hence about 0.8]. If this is acceptable, it would correspond to a ca. $39 \mathrm{~mm}$ height tooth. That amounts approximately to a nearly 4 meters total length animal (Gottfried et al., 1992).

Both cutting edges are denticulate, with rather irregularlyshaped and -sized denticles, not with lesser-sized and more regular denticles as in megalodon. We counted 39 denticles on the mesial cutting edge (in $36.8 \mathrm{~mm}$ or 0.94 denticles per millimetre) and 33 on the distal border (in $33.5 \mathrm{~mm}$ or 1.0 per $\mathrm{mm}$ ).

There is some damage in the middle part of the mesial cutting edge: one and maybe two denticles just disappeared and both the preceding three and the following one are incomplete, with loss of the point. Comparison with teeth from an extant specimen shows that cutting edges are absolutely intact in replacement teeth, as it would be expected, but used teeth could present closely similar damages on the mesial edge (and not so in the distal edge). Of course, the mesial edge is subject to a much more intense strain when biting bone or hard materials. Hence we can conclude the tooth under study was just lost after use, not necessarily after death.

The root also is quite flat, with a slightly concave border that shows no tendency to present distinct root branches, and so it also differs from megalodon. It shows a few foramina nutrientia.

The shape of the tooth allows us to recognize it as an upper lateral tooth, probably from the second file.

\section{DISCUSSION}

The observed characters leave absolutely no doubt that the specimen is an upper right lateral tooth, probably from the second file, from Carcharodon carcharias - the still living great white shark.

Size of the individual, ca. $4 \mathrm{~m}$ TTL, is of an adult, moderately large but well beyond the limits currently observed in extant specimens. Growth would be easier in seas not yet exploited by man and therefore much richer in prey, either cetaceans and pinnipeds or fishes. In the extant case, no exceptional size had been attained.

Geographic and time distribution of Carcharodon carcharias interested one of us for long (Antunes, 1978). It indeed was one of the leading elements of the Farol das Lagostas fauna in Angola that had been regarded as much older, lower Miocene, a confusion that arose from age interpretation of lower levels from the same Cuanza basin neogene series. Matter of fact, at the concerned upper levels at Cemitério dos Ossos and SECIL cement quarry the great white shark was quite common in an association that still included the giant Carcharocles megalodon, as we (M.T.A.) could verify in situ, where we collected teeth from both species. Discussion of the then available evidence allowed us to recognize a Pliocene age.

We also tried to gather information from elsewhere in order to clarify when did C. carcharias appear firstly. The first appearance datum of Carcharodon carcharias is indeed highly meaningful, since the species' expansion would most probably have been very fast.

Some of the references of occurrences in the Miocene were clearly erroneous. As far as Europe is concerned, the by far richest area where C. carcharias occurs is the Belgian basin, as it has clearly been shown by Leriche (1926: 465, where the synonym Carcharodon rondeleti Müller \& Henle, 1838, is used):

- C. carcharias does not at all occur in the Miocene (Bolderian stage);

- it firstly appears in Lower Pliocene (Anversian), where it coexists with megalodon;

- both species survived during the following successive stages, Diestian and Scaldisian. However it is scarce before the Scaldisian, where C. carcharias "semble remplacer C. megalodon" (Leriche, 1926: 424). These basic data did not change since then.

On the other hand, we had a previous experience on rich shark associations from successive levels of the Miocene of the lower Tagus Basin near Lisbon. Although megalodon is well represented in Upper Miocene, there is absolutely no evidence of carcharias there.

Our observations seem to match with those from Spain, in the Guadalquivir Basin and at Guardamar del Segura in Elche municipality (Alicante province, South-western Spain); sediments that produced the teeth belong to a member of the "Rojales Sandstone Formation" or Lower Pliocene unit II from the Bajo Segura Basin. As far as Carcharodon carcharias is concerned, none appeared before Pliocene (Adnet et al., in press).

As it has been recognized for the extant populations, it is "Very wide-ranging through most oceans; among the greatest habitat and geographic range of any fish" (Compagno et al., 2005: 182). It prefers moderately warm and warm temperate waters but may eventually go to colder ones, with a depth range from 0 to $1300 \mathrm{~m}$, from inshore to open ocean. "Satellite and genetic studies indicate that these sharks are highly migratory, crossing ocean basins and travelling annually between Mexico and Hawaii" (Compagno et al., 2005).

Travel may be rather fast. Rate of movement of sharks from South Australia averaged $3.2 \mathrm{~km} / \mathrm{hour}$ (Strong et al., 1996: 405), but can exceed it at least in short distances. A $490 \mathrm{~cm}$ TL female took a route of ca. $67 \mathrm{~km}$ in 26 hours (Strong et al., 1996: 409). Animals with such displacement capacities would appear in a quite brief time span in areas thousands of km away one another.

The appearance of Carcharodon carcharias in the Pliocene of Portugal could be expected. However, Portu- 
guese Pliocene selachian faunas remain nearly unknown, collected material being too scarce. The Marinha Grande occurrence does not even allow us to conclude the concerned species was rare, as it is at our times. As Albuquerque (1954-56: 89) states, its existence in the coastal Portuguese waters was doubtful, even if the species has been referred to since much earlier (Bocage \& Capello, 1866). As far as we could ascertain, it really is exceedingly rare: an adult specimen was captured near S. Miguel Island, Azores (Saldanha, 1995). Still another one was captured near the southern coast from Algarve, photographs being published in newspapers.

\section{CONCLUSIONS}

1. Fossil great white shark Carcharodon carcharias has been recognized for the first time in Portugal near Marinha Grande, in Pliocene, Zanclean to lower Piazencian in age sediments.

2. This occurrence further broadens its already huge, world-wide distribution in all major oceans and seas.

3 . It is indeed the first Pliocene vertebrate so far reported in Portugal.

4. The great white shark is represented but by a single upper right lateral (probably 2nd file) tooth lost after use from a ca. $4 \mathrm{~m}$ TL, adult individual.

5. The presence is very much in agreement with all known data about Iberian Peninsula, where it really has never been found in Miocene units but becomes common in lower Pliocene levels in Spain as at Guardamar de Segura.

6. Although the evidence is typical, it is too scarce to allow much speculation on the species numerical importance, but if we take into account that no other shark teeth are known in the concerned sediments it can provisorily be accepted that its occurrence would be rather common as at Guardamar de Segura.

7. This new record for the Pliocene in Portugal underlines the closeness of the first known occurrences for the eastern Atlantic, both in its northern (as this is the case) and southern parts as shown by the referred Pliocene fauna of Farol das Lagostas, Angola.

\section{ACKNOWLEDGEMENTS}

Professor Pedro Callapez (Coimbra University) promptly searched and found the specimen under study among the collections of the Coimbra University Science Museum under his care. He subsequently lent it to us for further examination. Very useful discussions on these matters and especially on the distribution of the great white shark were held with Dr. Henri-Charles Cappetta and Dr. Sylvain Adnet (Université Montpellier II). Comparisons with Spanish material from Elche were possible through the collaboration with Dr. J. M. Ferrer.

\section{REFERENCES}

Adnet, S., Balbino, A. C., Antunes, M. T. \& Ferrer, J. M. in press. A very big white shark in the early Pliocene of western Mediterranean. Neues Jahrbuch für Geologie und Paläontologie, Abhandlungen.

Albuquerque, R. M. 1954-56. Peixes de Portugal e Ilhas Adjacentes/ Chaves para a sua determinação. Portugaliae Acta Biologica, Série B, 5, 1164+3 pp., 445 fig.

Andres, L. in press. The temporal and geographical distribution of the fossil Great white shark (Carcharodon carcharias Linnaeus, 1758). Senckenbergiana lethaea.

Antunes, M. T. \& Jonet, S. 1970. Requins de l'Helvétien supérieur et du Tortonien de Lisbonne. Revista da Faculdade de Ciências de Lisboa, $2^{\mathrm{a}}$ série, C, 16, 119-280.

Antunes, M. T. 1978. Faunes ichthyologiques du Néogène supérieur d'Angola, leur âge, remarques sur le Pliocène marin en Afrique australe. Ciências da Terra (UNL), 4, 59-90.

Applegate, S. P. \& Espinosa-Arrubarrena, L. 1996. The fossil history of Carcharodon and its possible ancestor, Cretolamna: a study in tooth identification. In: Great White Sharks/ The Biology of Carcharodon carcharias (Eds. A. P. Klimley \& D. G. Ainley). Academic Press, San Diego, California/London, 19-36.

Balbino, A. C. 1995. Seláceos (Pisces) do Miocénico terminal da Bacia de Alvalade (Portugal)/ Sistemática, Ecologia, Paleoambientes, Comparação com as faunas actuais. Dissertação apresentada à Universidade de Évora para obtenção do grau de Doutor em Geologia especialidade de Paleontologia e Estratigrafia. 200 pp., 38 est., 1 p.+ 32 fig.

Bocage, J. B. du \& Capello, F. B. 1866. Peixes Plagiostomos - Esqualos, Apontamentos para a Icthiologia de Portugal. Typographia da Academia Real das Ciências, Lisboa, 40 pp.

Cappetta, H. 2006. Pars 142/ Elasmobranchii Post-Triadici (Índex specierum et generum). In: Fossilium Catalogus/ I: Animalia (ed. W. Riegraf). Backhuys Publishers, Leiden, $472 \mathrm{pp}$.

Compagno, L., Dando, M. \& Fowler, S. 2005. A field guide to the sharks of the world. Collins. Harper Collins Publishers Ltd., London, 368 pp.

Cox, L. R. 1936. Pliocene Mollusca from Portugal. Memórias e Notícias, Publicações do Museu Mineralógico e Geológico da Universidade de Coimbra, 9, 47-75.

Cox, L. R. 1941. New species of Gastropoda from the Pliocene of Portugal. Memórias e Notícias, Publicações do Museu Mineralógico e Geológico da Universidade de Coimbra, 10, 7-12.

Dollfus, G. F. \& Cotter, J. C. B. 1908. Mollusques tertiaires du Portugal/Le Pliocène au Nord du Tage (Plaisancien)/ $1^{r e}$ Partie - Pelecypoda/ Précédée d'une Notice Géologique. Commission du Service Géologique du Portugal. Imprimerie Nationale, Lisbonne, 24+103 pp.

Gottfried, M. D., Compagno, L. J. V. \& Bowman, S. C. 1992. Skeletal anatomy of Carcharodon megalodon: Inferences based on comparisons with the recent species Carcharodon carcharias. Journal of Vertebrate Paleontology, Suppl. 12 (3), 30A. 
Hubbell, G. 1996. Using tooth structure to determine the evolutionary history of the white shark. In: Great White Sharks/ The Biology of Carcharodon carcharias (Eds. A. P. Klimley \& D. G. Ainley). Academic Press, San Diego, California/London, 9-18.

Leriche, M. 1910. Les Poissons oligocènes de la Belgique. Mémoires du Musée Royal d'Histoire naturelle de Belgique, T.V. Mémoire 20, 329-364.

Leriche, M. 1926. Les Poissons néogènes de la Belgique. Mémoires du Musée Royal d'Histoire naturelle de Belgique, Mémoire V, 32, 365-472.

Morais, J. C. 1936. Geologia e Geografia da Região do Pinhal de Leiria/ Descrição Geológico-Geográfica da região do Pinhal de Leiria. Memórias e Notícias Publicações do Museu Mineralógico e Geológico da Universidade de Coimbra, 9, 5-46.

Morais, J. C. 1941. Mais alguns fósseis da região do Pinhal de Leiria/ Descrição Geológico-Geográfica da região do Pinhal de Leiria. Memórias e Notícias Publicações do Museu Mineralógico e Geológico da Universidade de Coimbra, 10, 3-5.
Saldanha, L. 1995. Fauna submarina atlântica. Ed. revista e aumentada. Publicações Europa-América. Mem Martins/ Portugal, $364 \mathrm{pp}$.

Silva, C. M. \& Landau, B. 2007. Cenozoic Atlanto-Mediterranean biogeography of Spiricella (Gastropoda, Umbraculidae) and climate change: Filling the geologic gap. The Veliger, 49, 19-26.

Strong, W. R., Bruce B. D., Nelson, D. R., Murphy, R. D. 1996. Population dynamics of white sharks in Spencer Gulf, South Australia. In: Great White Sharks/ The Biology of Carcharodon carcharias (Eds. A. P. Klimley \& D. G. Ainley). Academic Press, San Diego, California/ London, 401-416.

Zbyszewski, G. 1965. Carta Geológica de Portugal na escala de 1/50.000/ Notícia Explicativa da Folha 22-D/ MARINHA GRANDE. Direcção-Geral de Minas e Serviços Geológicos/ Serviços Geológicos de Portugal, 45 pp.

Manuscrito recibido: 13 de Noviembre, 2009 Manuscrito aceptado: 12 de Marzo, 2010 